\title{
Új kihívások és kutatási irányok az intézményi bizonytalanság korában
}

\author{
New challenges and research directions at a time of \\ institutional uncertainty
}

\author{
LUX GÁBOR
}

\begin{abstract}
LUX Gábor: tudományos főmunkatárs, Közgazdaság- és Regionális Tudományi Kutatóközpont, Regionális Kutatások Intézete; 7621 Pécs, Papnövelde u. 22.; lux.gabor@krtk.mta.hu; https://orcid.org/0000-0003-0948-3718

KULCSSZAVAK: regionális tudomány; nemzetközi láthatóság; intézményes bizonytalanság

Gábor LUX: senior research fellow, Institute for Regional Studies, Centre for Economic and Regional Studies; Papnövelde u. 22., H-7621 Pécs, Hungary; lux.gabor@krtk.mta.hu; https://orcid.org/00000003-0948-3718
\end{abstract}

KEYWORDS: regional science; internationalisation of sciences; institutional uncertainty

A korábbi évekkel ellentétben ma nehéz a magyar regionális tudomány helyzetét kincstári optimizmussal, vagy akár csak cselekvő pesszimizmussal is nézni. A magyar tudományt általában, és a társadalomtudományokat kiemelten kedvezőtlenül érintő változások súlyos mủködési és fenntarthatósági problémákat generálnak. A személyes és kollektív (intézményi) kiszolgáltatottság és a romboló bizonytalanság hatása konkrét pályaelhagyásokban, részleges vagy teljes kivonulási stratégiákban érhető tetten. Nem csak a kutatói utánpótlást érintő kérdésről van szó, hiszen kiszámíthatóság, tervezhető és vonzó jövőkép reménye nélkül a középgenerációt képviselő, tapasztalt, forrásszerzésben is jártas kutatók egy része is egyéni túlélési stratégiákat keres. A kutatói pálya gyengülő vonzereje a gyakori vélekedésekkel szemben nem csak a nemzetközi közegben is versenyképes legjobbakra, hanem a hazai tudományos kutatások derékhadát adó középmezőnyre is hatással van.

Ez a problémahalmaz különösen súlyos teher egy olyan külső feltételrendszerben, amelyben a nemzetközi láthatóság növekvő elvárás a kutatókkal és mühelyekkel szemben. Növekvő (bár gyakran irreális, illetve féloldalas mércékkel mérő) elvárások fogalmazódnak meg a külföldi publikációs aktivitással kapcsolatban; egyre fontosabbá válik, hogyan jelenünk meg a nemzetközi közegben. „Ott lenni” előfeltétel az eredmények disszeminációjában, a konzorciumi meghívásokban és a külső források elnyerésében, de az egyéni mobilitásban is. Bár a magyar regionalisták jelen vannak a nemzetközi térben, nem mindegy, hogy mi-

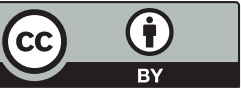


lyen pozícióban: beszállítóként és „saját tereikbe zárva” (csak szűk térbeli keretekre fókuszálva), önálló tudományos termékek előállítóiként, vagy éppen nagy kutatási témák koordinátoraiként és megfogalmazóiként. Ezen a ranglétrán nem könnyű feljebb lépni, és gyakran az elemi külföldi jelenlét (konferenciarészvétel, projektmegbeszélések látogatása) is esetleges, szűkös pályázati kereteken múlik. Ez ráadásul csak a küldő oldala, hiszen kutatókat Magyarországra hozni, vendégkutatókat fogadni még nehezebb feladat, bár ma már szerencsére találunk jó példákat is: a PTE KTK Regionális Innováció- és Vállalkozáskutatási Központjában tartott RIERC szemináriumok, a KRTK Agglomeráció és társadalmi kapcsolathálózatok kutatócsoportja, vagy az idén lezajlott, Sopronban megrendezett CERS (Central European Conference in Regional Science) konferencia előadói köre.

Ebben a nehéz és nem túl reményteli feltételrendszerben kell fenntartanunk a magyar regionális tudományt, és ebben támaszkodnunk kell meglévő erősségeinkre. A regionális tudománynak meg kell őriznie nyitottságát, képességét arra, hogy az eltérő diszciplínákból származó külső tudáselemeket integrálva kutassa a hazai és nemzetközi térfolyamatokat, hogy egyszerre legyen képes átfogó (szintetizáló) és fókuszált (mélyfúrásszerü) tudományos programok lebonyolítására, és hogy megőrizze szellemi és módszertani sokszínűségét, komplex szemléletét. A társadalmi tér kutatása egy soktényezős, tagolt, kölcsönhatásokban gazdag és ellentmondásokat is rejtő valóság megismerésének folyamata. A regionális tudományt ez élteti és teszi vonzóvá, nem válik javára a diszciplináris szűkkeblüség és a befelé fordulás.

Szükségünk van a folyamatos tartalmi megújulásra. Az elmúlt évtizedek kutatási kereteit gyakran a posztszocializmus nagy kérdései jelölték ki; nos, harminc évvel később már ez az átmenetinek hitt, generációnyinak bizonyult korszak is részben múlttá vált (Cseh Tamást és Bereményi Gézát idézve: „Túléltük hát, bár igénybe vett: s most itt vagyunk egy újabb fajta nagy pocsékolásban"). A szocializmus és a posztszocializmus öröksége része a minket érő hatások szélesebb csoportjának, de nem egyedüli vizsgálati keret, és nem helyes, ha behatárolja a gondolkodásunkat. A regionális fejlődésben az elmúlt évtizedekben új térformáló erők, problémák, kihívások - és új lehetőségek! - jelentek meg. Legyen szó a hálózatok és a digitalizáció alkotta új terekről, térstrukturáló hatásáról, a globális térfolyamatokról, a Budapest és a magyar vidék között húzódó szakadék kinyílásáról és tartóssá válásáról, a vidékies terek útkereséséről vagy a lokalizáció, a helyben gyökerező növekedési potenciál növekvő jelentőségéről - az új kérdések új kutatásokat igényelnek. A kutatások mögött pedig valós társadalmi kérdések, problémák állnak. A regionális tudomány missziója ezért nem korlátozódhat a slágertémák kutatására. Egy téma fontosságát nem csak aktuális hazai vagy nemzetközi divatossága, tudománymetriai mutatókra vagy pályázati pénzekre váltható ,árfolyama" határozza meg - hanem valami, ami ennél több. Ez lényeglátást, mérlegelést, és persze bőséges kutatói kíváncsiságot igényel. Mivel más nem nagyon lesz, ebből kívánhatunk sokat a következő évekre. 